\title{
PERAN SEKOLAH DAN ORANG TUA DALAM PELAKSANAAN PENDIDIKAN AGAMA ISLAM SISWA SMP NEGERI 3 YOGYAKARTA TAHUN PELAJARAN 2013/2014
}

\author{
Liya Nurul Habibah \\ PAI STIA Alma Ata Yogyakarta
}

\begin{abstract}
Abstrak
Penelitian ini bertujuan untuk mengetabui peran sekolab dalam pelaksanaan Pendidikan Agama Islam sehari-bari, mengetahui peran orang tua dalam melancarkan proses kegiatan belajar mengajar di sekolab dan kebidupan sehari-hari, mengetabui bubungan kerja sama sekolah dan orang tua dalam melancarkan proses kegiatan belajar mengajar di sekolah kbususnya pada Pendidikan Agama Islam. Jenis penelitian ini adalab penelitian lapangan. Adapun metode penelitian yang digunakan adalab kualitatif, sebagai penguat juga melakukan penelitian pustaka.

Hasil penelitian menunjukkan babwa adanya peran bersama antara sekolah dan orang tua dalam proses pelaksanaan Pendidikan Agama Islam anak. Hal ini dibuktikan dengan adanya kegiatan-kegiatan keagamaan yang dilaksanakan sekolah mendapat respon positif dari para orang tua. Perhatian yang diberikan orang tua kepada siswa menjadikan motivasi bagi para siswa untuk dapat meraib prestasi akademik yang baik serta memiliki akblak yang baik sesuai dengan tuntunan agama Islam dengan dukungan dari sekolah. Beberapa kegiatan dilaksanakan sekolab bertujuan untuk membantu orang tua dalam rangka mensukseskan pendidikan sekolab bagi para siswa.
\end{abstract}

Kata kunci: perhatian, keluarga, Pendidikan Agama Islam

\begin{abstract}
Abtract
This study aims to determine the role of schools in the implementation of Islamic Education everyday, knowing the parental role in launching the process of teaching and learning activities in schools and daily life, knowing the cooperation of school and parents in launching the process of teaching and learning activities in schools particularly in Islamic Education. This research is a field research. The research method used is qualitative, as the amplifier is also conducting research literature.
\end{abstract}


The results showed that the role of the joint between the school and parents in the process of implementation of Islamic education of children. This is evidenced by the religious activities conducted school received a positive response from parents. The attention given to the students' parents made the motivation for the students to be able to achieve a good academic record and have good morals in accordance with the guidance of Islam with the support of the school. Some of the activities carried out school aims to assist parents in order to succeed in school education for the students.

Keywords: attention, family, Islamic Education

\section{PENDAHULUAN}

Menurut UU No.20 tahun 2003 Sistem Pendidikan Nasional Bab 1 Pasal 1 ayat 1 :

"Pendidikan adalah usaha sadar dan terencana untuk mewujudkan suasana belajar dan proses peserta didik secara aktif mengembangkan potensi dirinya untuk memiliki kekuatan spiritual keagamaan, pengendalian diri, kepribadian, kecerdasan, akhlak mulia, serta keterampilan yang diperlukan dirinya, masyarakat, bangsa dan Negara".

Pendidikan memberikan kontribusi yang sangat besar terhadap kemajuan suatu bangsa dan merupakan wahana dalam menerjemahkan pesan-pesan konstitusi dan sarana dalam membangun watak bangsa. Masyarakat yang cerdas akan memberi nuansa kehidupan yang cerdas pula dan secara progresif akan membentuk kemandirian. ${ }^{2}$

Dalam pendidikan, kemajuan ilmu dan teknologi sangatlah pesat, dengan kemajuan ini memungkinkan terciptanya komunikasi bebas lintas benua, negara, provinsi, daerah perkotaan dan pedesaan melalui media audio dan audiovisual. Hampir tidak ada kehidupan yang belum tersentuh modernitas, termasuk kehidupan agama.Akibat dari kemajuan dan perkembangan berbagai media ini, dapat dijadikan alat untuk menanamkan atau marusak tatanan nilai-nilai spiritual keagamaan seseorang, khususnya peserta didik.Bila tidak ada peran sekolah dan orangtua dalam keluarga untuk menangani secara serius, nilai-nilai keagamaan ini akan sedikit demi sedikit hilang pada diri peserta didik.

\footnotetext{
${ }^{1}$ Abdullah Idi, Sosiologi Pendidikan Individu, Masyarakat dan Pendidikan, (Jakarta : PT Raja Grafindo Persada, 2011 ) hlm. 266

${ }^{2}$ E. Mulyasa, Manajemen Berbasis Sekolah, (Bandung : PT Remaja Rosda Karya, 2011 ) hlm. 4 
Pendidikan Agama, khususnya Pendidikan Islam pada hakikatnya bertujuan menyiapkan manusia menjadi khalifah (pemimpin) di bumi dan sebagai hamba yang mengabdi kepada Tuhan-Nya dalam keadaan apapun dan dimanapun. Seperti dalam firman Allah dalam Q.S. Al-Baqarah : 30

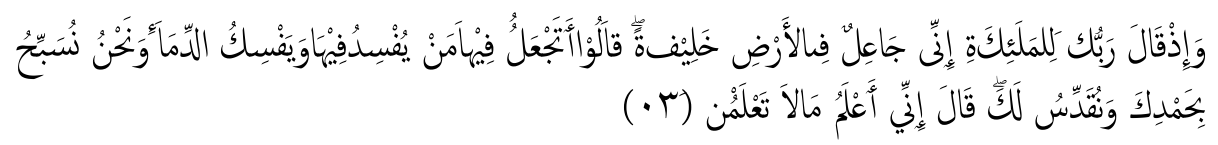

Artinya:

Dan (ingatlah) ketika Tubanmu berfirman kepada malaikat: "Sesunggubnya Aku bendak menjadikan seorang khalifah di bumi". Mereka bertanya (tentang bikmab ketetapan Tuban itu dengan berkata): "Adakab Engkau (Ya Tuban kami) hendak menjadikan di bumi itu orang yang akan membuat bencana dan menumpabkan darab (berbunub-bunuban), padahal kami senantiasa bertasbih dengan memujiMu dan mensucikanMu?” Tuban berfirman: " Sesunggubnya Aku mengetahui akan apa yang kamu tidak mengetabuinya”

Ketika Allah menjadikan manusia sebagai khalifah dimuka bumi dan dengannya Allah SWT mengamanahkan bumi beserta isi kehidupannya kepada manusia, maka manusia merupakan wakil yang memiliki tugas sebagai pemimpin di bumi Allah.Pendidikan Islam sekaligus menyiapkan sumber dayanya untuk mampu menghadapi masyarakat dengan segala kebaikan dan kejahatannya serta kenikmatan dan kesusahannya.Perkembangan dan pertumbuhan manusia yang beragama ditentukan oleh faktor lingkungan sekolah dan lingkungan keluarga.

Tujuan Pendidikan menurut AL-Qur'an yang menjadikan pedoman dan pegangan hidup umat Islam terdapat dalam firman Allah Q.S Ali-Imran : 138

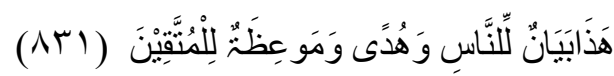

Artinya:

(Al-Qur'an) ini adalah penerangan bagi selurub manusia dan petunjuk serta pelajaran bagi orang-orang yang bertakwa

Sedangkan tujuan dalam Pendidikan Islam yang diberikan di sekolah adalah untuk mencerdaskan dan mengembangkan pola pikir peserta didik dan menata tingkah laku peserta didik dan emosinya serta menanamkan nilai-nilai positif yang sesuai pandangan Islam dan kehidupan di masyarakat. Tujuan pendidikan Islam yang diberikan di rumah adalah mengembangkan materi yang ada di sekolah sehingga peserta didik dapat menerapkan dan mempraktikkannya yang nantinya akan berguna bagi kehidupan. 
Segala aktivitas pendidikan, belajar mengajar dan sebagainya adalah termasuk dalam kategori ibadah. Hal ini terkait dengan Sabda Nabi Muhammad SAW

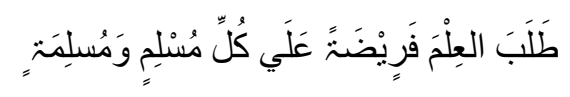

\section{Artinya:}

"Menuntut ilmu adalah fardhu bagi orang Islam laki-laki dan perempuan"

Menurut Islam belajar mengajar termasuk kedalam pelaksanaan ibadah dan terkait dengan dunia pendidikan adalah belajar mengajar merupakan suatu proses yang berkesinambungan dalam dunia pendidikan. Proses belajar mengajar tidak terbatas pada kegiatan penyampaian materi pelajaran di kelas, tetapi yang lebih penting adalah bagaimana agar materi pelajaran yang diterima siswa di kelas dapat diterapkan dan diamalkan dalam kehidupan sehari-hari. Keberhasilan proses belajar mengajar sangat ditentukan oleh kualitas dan profesionalisme guru agama. ${ }^{3}$

Pelaksanaan jam pelajaran di sekolah, khususnya mata pelajaran agama tidak dapat menjamin seluruh materi Pendidikan Agama Islam dapat sampai kepada siswa secara maksimal. Tercapainya tujuan pembelajaran dalam Pendidikan Islam dapat dicapai dengan peran serta orang tua dalam proses pembelajaran peserta didik di lingkungan keluarga. Dukungan dan peran serta orang tua dalam proses belajar peserta didik dapat memaksimalkan tumbuh dan kembang peserta didik dalam memperoleh pengetahuan khususnya dalam Pendidikan Agama Islam.Menurut Undang-undang Sistem Pendidikan Nasional No. 20 Tahun 2003 pasal 7 yang berisi (1) orangtua berhak berperan serta dalam memilih satuan pendidikan dan memperoleh informasi tentang perkembangan pendidikan anaknya. (2) orangtua dari anak usia wajib belajar, berkewajiban memberikan pendidikan dasar kepada anaknya. ${ }^{4}$

Kegiatan belajar mengajar menjadi tanggung jawab guru mata pelajaran di masing-masing bidang mata pelajaran.Khususnya mata pelajaran Pendidikan Agama Islam memiliki waktu pelajaran selama 2x40 menit selama satu minggu. Seluruh materi belum tentu dapat disampaikan secara maksimal, karena minimnya waktu yang diberikan dan juga praktik Pendidikan Agama Islam yang seharusnya diterapkan juga belum dapat maksimal. Guru bidang studi Pendidikan Agama Islam saja yang biasa bertanggung jawab atas praktik

${ }^{3}$ Fak.Tarbiyah IAIN Walisongo Semarang, PBM-PAI di Sekolah. Eksistensi dan Proses Belajar Mengajar PAI, (Yogyakarta : Pustaka Pelajar Offset, 1998), hlm. xvi

${ }^{4}$ Abdullah Idi, Sosiologi Pendidikan Individu .....,hlm. 269 
Pendidikan Agama, khususnya praktik ibadah yang dilaksanakan di sekolah. Kurangnya perhatian dari beberapa guru bidang studi yang lain mempengaruhi kebiasaan, sikap dan perilaku peserta didik dan juga minimnya pengawasan dan perhatian dari orangtua mengenai proses pembelajaran khususnya Pendidikan Agama Islam.

Sungguh pun, kedudukan Pendidikan Agama Islam sebagai subsistem dari Sistem Pendidikan Nasional cukup kuat, dalam pelaksanaan masih dijumpai beberapa masalah, antara lain: kurangnya jumlah jam pelajaran, metodologi pendidikan agama yang kurang tepat, adanya dikotomi antara pendidikan agama dengan pendidikan umum, heteroginitas pengetahuan dan penghayatan agama peserta didik dan perhatian dan kepedulian pimpinan sekolah dan guru-guru lain. ${ }^{5}$

Seharusnya peran dan fungsi orang tua dalam pendidikan agama perlu digalakkan, seperti memanggil guru privat atau mengirimkan anaknya ke Taman Pendidikan Al-Qur'an atau Madrasah Diniyah atau Pesantren Kilat.Yang paling penting bagi pendidikan agama anak adalah menciptakan "suasana Keagamaan" dalam kehidupan sehari-hari baik secara langsung atau tidak langsung. Apabila hal ini dapat dilaksanakan maka kurang atau terbatasnya jam pelajaran agama di sekolah dapat dibantu oleh pendidikan agama dalam keluarga. ${ }^{6}$

Kurangnya perhatian orangtua terhadap Pendidikan Agama Islam baik di sekolah maupun di rumah sangat berpengaruh terhadap kebiasaan dan perilaku yang dimiliki oleh anak. Berdasarkan pra penelitian yang penulis lakukan terhadap siswa-siswi SMP Negeri 3 Yogyakarta, terdapat kurang perhatian para siswa terhadap materi Pendidikan Agama Islam di sekolah, akibatnya hanya pada mata pelajaran umumlah yang sangat unggul dan mendapat prestasi baik, sedangkan pada mata pelajaran Pendidikan Agama Islam hanya didapat oleh beberapa siswa saja itupun karena siswa tersebut mendapat pendidikan agama yang lebih dari keluarganya. Pada kegiatan-kegiatan keagmaan yang dilaksanakan di sekolah pun kurang mendapat perhatian yang lebih oleh para siswa, seperti adanya tadarus Al-Qur'an yang dilaksanakan serentak, hanya beberapa siswa saja yang dalam membaca Al-Qur'annya lancar dan baik sedangkan yang lainnya kurang bahkan ada yang belum bisa membaca, selain tadarus ada kegiatan shalat dhuha dan dhuhur berjamaah di sekolah, beberapa dari mereka ada yang mengikuti dengan khusyuk tetapi ada pula yang mengikuti dengan tidak khusyuk bahkan ada yang meminta ijin untuk tidak mengikuti dengan alasan-alasan yang bermacam-macam. Kurangnya perhatian siswa terhadap perilaku keagamaan

${ }^{5}$ Ibid, hlm.5

${ }^{6}$ Ibid, hlm.7

LITERASI, Volume V, No. 2 Desember 2014 
dalam diri mereka seharusnya mendapatkan perhatian yang lebih dari para guru, tidak hanya guru mata pelajaran Pendidikan Agama Islam saja dan juga perhatian dari para orangtua siswa untuk lebih memperhatikannya ketika berada dirumah, karena kebiasaan baik dirumah tentunya akan mendorong perilaku dan sikap yang baik pula disekolah.

Berdasarkan uraian pada latar belakang, maka dapat dirumuskan permasalahannya dalam penelitian ini sebagai berikut: Pertama bagaimana peran sekolah dalam pelaksanaan Pendidikan Agama Islam siswa SMP Negeri 3 Yogyakarta? Kedua bagaimana peran orang tua dalam pelaksanaan Pendidikan Agama Islam anak di rumah? Ketiga bagaimana hubungan kerjasama antara sekolah dan orang tua dalam proses pembelajaran Pendidikan Agama Islam anak?

Tujuan utama dari penelitian ini adalah untuk mengetahui sejauh mana "Peran Sekolah dan Orang tua dalamPelaksanaan Pendidikan Agama Islam Siswa di SMP Negeri 3 Yogyakarta". Namun secara spesifik tujuan penelitian ini bertujuan untuk memperoleh informasi dan kejelasan tentang mengetahuai peran sekolah dalam pelaksanaan Pendidikan Agama Islam seharihari, mengetahui seberapa besar peran orang tua dalam melancarkan proses kegiatan belajar mengajar di sekolah dan kehidupan sehari-hari, dan mengetahui hubungan kerjasama sekolah dan orang tua dalam melancarkan proses kegiatan belajar mengajar disekolah khususnya pada Pendidikan Agama Islam anak.

\section{METODE PENELITIAN \\ Jenis Penelitian}

Jenis penelitian ini adalah penelitian lapangan. Metode penelitian yang digunakan adalah metode kualitatif, sebagai penguat juga melakukan penelitian pustaka untuk memperoleh teori dan sumber yang relevan dengan permasalahan yang diteliti.Hal ini bertujuan untuk mendapatkan hasil atau pemaknaan sosial melalui berbagai perspektif masyarakat atau dalam hal ini adalah orang tua siswa siswi SMP Negeri 3 Yogyakarta.

\section{Subjek Penelitian} berikut :

Pada penelitian ini yang dijadikan subjek penelitian ini adalah sebagai

\section{Kepala SMP Negeri 3 Yogyakarta bapak Drs. Marsono, M. M.}

Kepala sekolah disini sangat berperan penting dalam pemberian informasi yang berkaitan dengan perkembangan proses pendidikan yang ada 
di sekolah. Khususnya dalam proses pendidikan agama, karena kepala sekolah mempunyai tugas dalam mengatur dan bertanggung jawab atas segala kegiatan dan proses belajar. Kepala sekolah sebagai administrator dan supervisor dalam dua bidang yaitu administrasi dan edukatif.Dalam bidang administrasi kepala sekolah mempunyai tugas untuk mengatur dan bertanggung jawab terhadap :
a. Kesiswaan
b. Personilia
c. Alat pengajaran
d. Peralatan gedung dan pemeliharaan
e. Keuangan
f. Hubungan dengan masyarakat

Dalam bidang teknik edukatif, kepala sekolah mempunyai tugas mengatur dan menilai proses belajar yang meliputi :

1) Bidang satuan pelajaran

2) Kegiatan belajar mengajar guru kelas

3) Kegiatan BK

4) Kegiatan ekstrakurikuler

Guru PAI SMP Negeri 3 Yogyakarta yang berjumlab 2 orang yaitu ibu Setiyawati, S. Pd. I. dan bapak Machsun, S. Ag. Tugas guru di SMP Negeri 3 Yoyakarta adalab

a. Melaksanakan kurikulum yang berlaku

b. Melaksanakan administrasi pendidikan

c. Bertindak sebagai panutan atau contoh yang baik bagi para siswa

Guru PAI disini juga mempunyai peran yang sangat penting sebagai pemberi informasi dan materi Pendidikan Agama Islam yang sesuai dengan jenjang pendidikan dan kurikulum yang berlaku di sekolah.

\section{Siswa SMP Negeri 3 Yogyakarta.}

Tugas siswa disekolah adalah

a. Melaksanakan segala tata tertib yang telah ditentukan

b. Belajar di kelas dengan penuh tanggung jawab

c. Melalui organisasi kesiswaan atau pengurus kelas mengembangkan $5 \mathrm{~K}$ (keamanan, ketertiban, keindahan, kekeluargaan dan ketaqwaan) 


\section{Orang tua/Wali siswa yang beragama Islam di SMP Negeri 3 Yogyakarta.}

Wali siswa sangat berperan penting dalam mamantau dan memberikan pengarahan dan pengetahuan di lingkungan keluarga. Keluarga memberikan dukungan dan motivasi dalam proses pendidikan anak, khususnya dalam Pendidikan Agama Islam yang tentunya masih berkaiatan dengan materi pelajaran disekolah.

\section{Waktu dan Tempat Penelitian Waktu Penelitian}

Waktu penelitian ini dilaksanakan tanggal 13 Januari 2014 sampai dengan 29 Maret 2014.

\section{Tempat Penelitian}

Penelitian ini berlokasi di SMP Negeri 3 Yogyakarta.Yang beralamat di jalan Pajeksan No. 18 Yogyakarta. Sekolah ini terletak di tepi jalan Malioboro yang menjadi satu jalan yang menghubungkan pusat kota Yogyakarta.

\section{Teknik Pengumpulan Data Observasi}

Menurut Sutrisno Hadi,1986, observasi sebagai teknik pengumpulan data. Observasi merupakan suatu proses yang kompleks, proses yang tersusun dari berbagai proses biologis dan psikologis. Teknik pengumpulan data dengan observasi digunakan bila penelitian berkenaan dengan perilaku manusia, proses kerja, gejala-gejala alam dan bila responden yang diamati terlalu besar. ${ }^{7}$

Sanafiah Faisal, 1990, mengklasifikasikan observasi menjadi observasi berpartisipasi, observasi yang terang-terangan dan tersamar dan observasi yang tak terstruktur. ${ }^{8}$

Teknik ini digunakan untuk mengamati langsung permasalahan yang diteliti dan dari pengamatan yang ditemukan di lapangan, ini dilakukan sebagai pengamatan terhadap fenomena-fenomena yang terjadi. Teknik observasi merupakan proses yang kompleks, suatu proses yang tersusun dari proses biologis dan psikologis, yaitu proses pengamatan dan proses ingatan. Teknik ini bertujuan untuk mengetahui Peran Sekolah dan Orang tua dalam Pelaksanaan Pendidikan Agama Islam Siswa di SMP Negeri 3 Yogyakarta tahun pelajaran 2013/2014.

${ }^{7}$ Ibid, hlm. 203

${ }^{8}$ Ibid, hlm. 210 


\section{Wawancara}

Wawancara digunakan sebagai teknik pengumpulan data apabila peneliti ingin melakukan studi pendahuluan untuk menemukan permasalahan yang harus diteliti dan juga apabila peneliti ingin mengetahui hal-hal dari responden yang lebih mendalam dan jumlah respondennya sedikit atau kecil. Teknik pengumpulan data ini mendasar diri pada laporan tentang diri sendiri atau setidak-tidaknya pada pengetahuan dan keyakinan pribadi. Sutrisno Hadi, mengemukakan bahwa anggapan yang perlu dipegang oleh peneliti dalam menggunakan teknik interview dan juga angket adalah sebagai berikut

a. Bahwa responden adalah orang yang paling tahu tentang dirinya sendiri.

b. Bahwa apa yang dinyatakan oleh responden kepada peneliti adalah benar dan dapat dipercaya.

c. Bahwa interpretasi responden tentang pertanyaan-pertanyaan yang diajukan peneliti kepadanya adalah sama dengan apa yang dimaksudkan oleh peneliti.

Wawancara dapat dilakukan secara terstruktur maupun tidak terstruktur dan dapat dilakukan malalui tatap muka maupun dengan menggunakan telepon. ${ }^{9}$

Data pertama yang akan di ambil dalam teknik wawancara adalah data yang berkaitan dengan profesiomalisme seorang guru dalam memberikan pelajaran di dalam kelas. Wawancara yang dilakukan penulis dilaksanakan pada saat jam istirahat berlangsung dengan kedua guru bidang studi Pendidikan Agama Islam di SMP Negeri 3 Yogyakarta. Untuk mendukung hasil wawancara tersebut penulis juga melakukan wawancara untuk mengambil data mengenai profesionalisme kinerja guru di dalam kelas yang telah dipantau oleh kepala sekolah SMP Negeri 3 Yogyakarta, yaitu bapak Drs. Marsono, M. M.

Wawancara selanjutnya dilakukan oleh penulis dengan beberapa wali siswa/orangtua siswa SMP Negeri 3 Yogyakarta.Wawancara dilakukan guna memperoleh data orangtua berkaitan dengan seberapa besar orangtua/wali siswa memberikan perhatian dan memfasilitasi belajar anak saat mereka berada di rumah atau di luar sekolah.

\section{Angket}

Angket merupakan teknik pengumpulan data yang dilakukan dengan cara memberi seperangkat pertanyaan atau pernyataan tertulis kepada responden untuk dijawabnya. Angket merupakan teknik pengumpulan data yang paling efisien bila peneliti tahu dengan pasti variabel yang akan diukur dan tahu apa

${ }^{9}$ Ibid, hlm. 194

LITERASI, Volume V, No. 2 Desember 2014 
yang bias diharapkan dari responden. Selain itu angket juga cocok digunakan bila jumlah responden cukup besar dan tersebar diwilayanh yang luas. Angket dapat berupa pertanyaan atau pernyataan tertutup atau terbuka, dapat diberikan kepada responden secara langsung atau dikirim melalui pos atau internet. ${ }^{10}$

Format dan susunan angket hendaknya menarik, menyenangkan untuk dilihat, mudah dipahami. Pertanyaan disusun dengan rapi dan tidak mengorbankan banyak waktu dan pikiran terlalu banyak.

Angket sebagai sumber pengumpulan data dalam penelitian ini disebarkan menjadi 3 kelomok, yaitu :

a. Angket yang berkaitan dengan profesionalisme kinerja guru bidang studi Pendidikan Agama Islam di SMP Negeri 3 Yogyakarta,

b. Angket siswa, angket ini bertujuan untuk mengetahui seberapa besar siswa memberikan perhatiannya kepada mata pelajaran Pendidikan Agama Islam dan seberapa besar pengaruh mata pelajaran Pendidikan Agama Islam dengan perilaku siswa dalam kehidupan sehari-hari baik di sekolah maupun di luar sekolah.

c. Angket orang tua siswa/wali siswa, angket ini berisikan tentang seberapa besar orang tua/wali siswa memberikan perhatian kepada perilaku anak sehari-hari, dan mengukur seberapa besar peran kedua orang tua terhadap perkembangan pendidikan anak, khususnya pada pendidikan agama anak.

\section{Dokumentasi}

Dokumentasi yaitu teknik pengumpulan data melalui benda-benda tertulis, buku, majalah, dokumen, peraturan-peraturan, notulen rapat, catatan harian, dan sebagainya. Semuanya berkaitan dengan Peran Sekolah dan Orang tua dalam Pelaksanaan Pendidikan Agama Islam Siswa di SMP Negeri 3 Yogyakarta.Studi dokumen merupakan pelengkap dari teknik pengumpulan data dalam penelitian ini.

\section{Analisis Data}

Analisis data dalam penelitian ini, dilakukan pada saat pengumpulan data berlangsung dan setelah pengumpulan data dalam periode tertentu.Miles dan Huberman, 1984, mengemukakan bahwa aktivitas dalam analisis data kualitatif dilakukan secara interaktif dan berlangsung secara terus-menerus sampai tuntas, sehingga datanya sudah jenuh. Aktivitas dalam analisis data, yaitu :

${ }^{10}$ Ibid, hlm. 199 


\section{Reduksi data}

Mereduksi data berarti merangkum, memilih hal-hal yang pokok, memfokuskan pada hal-hal yang penting, dicari tema dan polanya dan membuang yang tidak perlu.

\section{Penyajian data}

Penyajian data ini dapat dilakukan dalam bentuk tabel, grafik, phie card, pictogram dan sejenisnya. Melalui penyajian data tersebut, maka data terorganisasikan, tersusun dalam pola hubungan, sehingga akan semakin mudah difahami.

\section{Verifikasi}

Langkah ketiga dalam analisis data penelitian ini adalah penarikan kesimpulan dan verifikasi. Kesimpulan awal yang dikemukakan masih bersifat sementara dan akan berubah bila tidak ditemukan bukti-bukti yang kuat yang mendukung pada tahap pengumpulan data berikutnya. Kesimpulan dalam penelitian kualitatif yang diharapkan adalah merupakan temuan baru yang sebelumnya belum pernah ada. ${ }^{11}$

\section{HASIL PENELITIAN DAN PEMBAHASAN Hasil Penelitian}

\section{Peran Sekolab dalam Pelaksanaan Pendidikan Agama Islam SMP Negeri 3 Yogyakarta}

Berdasarkan penelitian yang telah dilakukan oleh penulis di SMP Negeri 3 Yogyakarta menunjukkan bahwa adanya peran sekolah terhadap Pendidikan Agama Islam siswa SMP Negeri 3 Yogyakarta.Peran sekolah dalam Pendidikan Agama Islam siswa ditunjukkan dengan berbagai kegiatan-kegiatan keagamaan yang dilaksanakan di sekolah, baik dalam kegiatan akademik maupun non akademik.Kegiatan keagamaan yang dilaksanakan di SMP Negeri 3 Yogyakarta sangat beragam. Terlebih pada saat datangnya bulan Ramadhan di SMP Negeri 3 Yogyakarta akan banyak sekali diadakan kegiatan-kegiatan keagamaan, khususnya pada siswa yang beragama Islam. Untuk kegiatan rutin yang dilaksanakan di SMP Negeri 3 Yogyakarta adalah

Pelaksanaan shalat Dhuha

Pelaksanaan shalat Dhuha dilaksanakan setiap hari pada saat jam istirahat pertama, pada jam 09.45-10.00 bertempat di masjid Cahyo Wiyati. Kegiatan ini di

${ }^{11}$ Ibid, hlm. 337

LITERASI, Volume V, No. 2 Desember 2014 
tujukan kepada seluruh siswa siswi SMP Negeri 3 Yogyakarta yang beragama Islam dari kelas VII sampai denga kelas IX, tidak hanya siswa siswinya saja, tetapi juga guru dan staf karyawan yang beragama Islam juga dihimbau untuk melaksanakannya.

Pelaksanaan shalat Dhuhur berjamaah

Pelaksanaan shalat Dhuhur berjamaah sesuai dengan jadwal yang telah dibuat oleh guru bidang studi Pendidikan Agama Islam.Dibuatnya jadwal shalat berjamaah ini dimaksudkan agar siswa siswi dapat disiplin melaksanakan shalat Dhuhur berjamaah di sekolah dan untuk memantau kedisiplinan siswa dalam melaksanakan shalat wajib.Dibuatnya jadwal pelaksanaan karena melihat kondisi masjid yang tidak mungkin menampung seluruh siswa siswi, guru dan staf karyawan untuk berjamaah shalat Dhuhur.

Pelaksanaan shalat Jum'at

Pelaksanaan shalat Jum'at bagi para siswa sesuai jadwal yang telah dibuat oleh guru bidang studi Pendidikan Agama Islam.Dilaksanakan berjamaah kelas VII pada minggu pertama, kelas VIII pada minggu kedua, kelas IX pada minggu ketiga dan seterusnya. Sesuai jadwal ada piket kelas yang bertugas sebagai khatib, muadzin dan piket membersihkan dan merapikan masjid untuk mempersiapkan shalat Jum'at. Pelaksanaan shalat Jum'at ini wajib bagi kelas yang bertugas dan yang telah sesuai jadwal, karena telah disediakan absen, bagi siswa yang tidak mengikuti akan mendapat sanksi yaitu merangkum khutbah shalat Jum'at dan kegiatan ini termasuk kedalam penilaian keaktifan siswa pada pelajaran Pendidikan Agama Islam.

Tabel 1. Jadwal Piket Pelaksanaan Shalat Jum'at dan Kajian Islami

\begin{tabular}{cccc}
\hline Minggu ke Januari & Kelas & Piket & Kajian Islami \\
\hline III & VII & VIIA & VII A \\
IV & VIII & VIII A & VII IA \\
\hline \multicolumn{4}{c}{ Minggu ke Bulan Februari } \\
\hline I & IX & IXA & IX A \\
II & VII & VIIB & VII B \\
III & VIII & VIIIB & VIII B \\
IV & IX & IXB & IX B \\
\hline Minggu ke Bulan Maret & Kelas & Piket & Kajian Islami \\
\hline I & VII & VIIC & VII C \\
II & VIII & VIII C & VIII C \\
III & IX & IX C & IX C \\
IV & VII & VII D \\
\hline \multicolumn{4}{c}{}
\end{tabular}


Kajian Islami bagi siswi SMP Negeri 3 Yogyakarta yang diisi oleh relawan mahasiswa Jogja

Kajian Islami bagi para siswi pada hari Jum'at bersamaan dengan pelaksanaan shalat Jum'at.Kajian Islami dilaksanakan di kelas masing-masing sesuai dengan jadwal kelas yang melaksanakan shalat Jum'at berjamaan di sekolah.Di bimbing oleh para mahasiswa Jogja yang dibertugas di SMP Negeri 3 Yogyakarta.Isi dari kajian islami ini bermacam-macam sesuai dengan tema atau diskusi yang ingin disampaikan di dalam kelas. Keikut sertaan pada kegiatan ini adalah wajib karena akan menambah nilai pada kegiatan non akademik siswa.

Infaq rutin setiap hari Jum'at yang dikoordinir oleh angota ROHIS SMP Negeri 3 Yogyakarta

Infaq rutin yang dilaksanakan pada hari Jum'at dengan bantuan anggota Rohish SMP Negeri 3 Yogyakarta dan guru wali kelas masing-masing pada saat jam istirahat. Pada bulan Ramadhan, infaq dilaksanakan setiap hari selama kegiatan belajar mengajar berlangsung.

Pelaksanaan kegiatan bakti sosial dan zakat, yang disalurkan kepada warga sekitar SMP Negeri 3 Yogyakarta yang membutubkan dan sebagian disalurkan kedaerabdaerah yang masib membutubkan zakat

Pelaksanaan bakti sosial pada saat Ramadhan, barang yang disumbangkan berupa uang tunai, beras ataupun pakaian layak pakai yang akan disumbangkan kepada warga sekitar SMP Negeri 3 Yogyakarta dan daerah tertentu yang membutuhkan. Pada pelaksanaan Bakti Sosial pada tahun 2013 dilaksanakan pada hari Rabu tanggal 31 Juli 2013 di dusun Balerante, Klaten Yogyakarta.

\section{Pengajian memperingati hari besar Islam}

Pengajian yang dilaksanakan insidental sesuai dengan perayaan Hari Besar Islam, seperti pengajian Isra' Mi'raj, pengajian rutin keluarga SMP Negeri 3 Yogyakarta.

\section{Lomba-lomba keagamaan tingkat daerah sampai Nasional}

Mengikuti lomba keagamaan tingkat daerah sampai dengan Nasional SMP Negeri 3 Yogyakarta juga pernah mengikuti lomba keagamaan seperti lomba CCA, adzan, kaligrafi dan beberapa lomba keagamaan lainnya pada tingkat daerah kota Yogyakarta. 


\section{Tadarus rutin}

Kegiatan ini dilaksanakan rutin pada saat bulan Ramadhan pada jam 07.00-07.15 secara berjamaah dengan dipimpin oleh siswa yang bertugas atau guru yang bertugas. Tadarus yang dilaksanakan untuk meningatkan kemampuan siswa dan siswi dalam membaca Al-Qur'an.

\section{Pesantren kilat dan buka bersama}

Kegiatan ini dilaksanakan pada saat bulan Ramadhan.Pesantren kilat untuk kelas VII dilaksanakan diluar sekolah, yaitu di panti asuhan/ pesantren anak yang berada di wilayah Yogyakarta.Pelaksanaan pesantren kilat dan buka bersama bagi kelas VIII dan IX dilaksanakan di sekolah mulai sore hari sampai setelah shalat tarawih. Pada Ramadhan tahun 2013 kegiatan ini dibagi dalam dua hari yaitu pada hari Jum'at tanggal 26 Juli 2013 buka bersama dengan siswi SMP Negeri 3 Yogyakarta dan pada hari Sabtu tanggal 27 Juli 2013 buka bersama dengan siswa SMP Negeri 3 Yogyakarta. Kegiatan ini banyak diisi materi keagamaan yang pada saat itu diisi oleh mahasiswa dan mahasiswi STIA ALMA ATA .

Pelaksanaan kegiatan pesantren kilat diadakan pada hari Senin tanggal 29 Juli-30 Juli 2013 bagi siswa sisiwi kelas VII di Panti Asuhan Sinar Melati Sleman, Yogyakarta.

Kegiatan ini dilaksanakan secara rutin oleh pihak sekolah bertujuan untuk mengajarkan siswa siswi untuk memperdalam pembelajaran agama dan meningkatkan kualitas ibadah para siswa pada bulan Ramadhan.

Kegiatan-kegiatan tersebut tentunya mendapat izin dan dukungan dari kepala sekolah SMP Negeri 3 Yogyakarta dan didukung para guru dan karyawan, oleh karena itu kegiatan-kegiatan tersebut selalu mendapat perhatian seluruh guru dan pihak sekolah. ${ }^{12}$

Beberapa kegiatan dalam pelaksanaannya masih membutuhkan beberapa perbaikan, seperti memaksimalkan waktu pelaksanaannya dengan bantuan dan kerjasama dengan para guru dan staf SMP Negeri 3 Yogyakarta, agar tidak berhenti atau setengan-setengah dalam menjalankan kegiatan-kegiatan tersebut. Motivasi dan dorongan dari para guru dan teman akan menumbuhkan rasa percaya diri bagi para siswa dan menambah semangat pada diri siswa dalam keikutsertaan pelaksanaan kegiatan tersebut.

${ }^{12}$ Hasil wawancara dengan Kepala SMP Negeri 3 Yogyakarta di ruang Kepala Sekolah dan hasil observasi penulis pada saat praktik pengalaman lapangan (PPL) di SMP Negeri 3 Yogyakarta pada tanggal 22 Maret 2014 
Tidak hanya peran sekolah yang penting bagi keberhasilan proses pembelajaran di sekolah, khusunya bagi Pendidikan Agama Islam siswa tanpa didampingi oleh guru. Guru merupakan orang yang paling utama dan bertanggung jawab atas pelaksanaan kegiatan belajar mengajar didalam kelas. Lancar atau tidaknya proses pembelajaran bergantung pada persiapan seorang guru sebelum memasuki kelas sampai memberikan materi pelajaran kepada siswa. Oleh karena itu sebelum memasuki ruang kelas, guru sudah terlebih dahulu mempersiapkan dan merancang dengan sebaik-baiknya materi yang akan disampaikan, semua hal yang dipandang perlu dalam kegiatan pembelajaran telah disiapkan, baik itu persiapan fisik, mental, buku paket/buku pelajaran, materi maupun metode yang akan digunakan dan disampaikan ketika berada didalam kelas.

Menurut hasil angket dan wawancara yang dilakukan penulis dengan guru mata pelajaran Pendidikan Agama Islam, yaitu ibu Setiyawati, S.Pd.I dan bapak Machsun S.Ag, dari cara guru memberikan dan mengkaitkan mata pelajaran Pendidikan Agama Islam dengan sumber lain atau mata pelajaran lain adalah baik, karena guru dalam menyampaikan materi pelajaran didukung dengan beberapa sumber dan situasi dalam kehidupan sehari-hari, jadi dapat lebih mudah dipahami oleh siswa. Guru menunjukkan sikap yang sangat interaktif ketika berinteraksi dengan siswa, sehingga siswa tidak canggung ketika ingin bertanya dan tidak merasa tegang ketika pelajaran dimulai. Interaksi dan komunikasi yang baik diciptakan oleh para guru tidak hanya disaat jam pelajaran ketika di kelas tetapi juga diluar kelas dan diluar sekolah. Terkait dengan profesionalisme dalam mengajar dapat dikatakan baik pula karena dengan komunikasi yang baik maka proses belajar mengajar di dalam kelas juga akan baik dan mendukung cara guru dalam menyampaikan materi dengan baik. Evaluasi dan penilaina selalu dilakukan oleh guru setiap selesai mengajar dan tidak lupa guru juga memberikan tugas dan latihan untuk mengetahui seberapa besar mereka memperhatikan materi yang telah disampaikan. ${ }^{13}$

\section{Peran Orang tua dalam Pelaksanaan Pendidikan Agama Islam Sebari- bari Anak}

Berdasarkan penelitian yang telah dilakukan penulis terhadap orang tua siswa SMP Negeri 3 Yogyakarta menunjukkan bahwa ada peran keluarga khususnya peran orang tua terhadap Pendidikan Agama Islam anak dalam segala kegiatan dan aktivitas yang dilakukan di rumah. Pendidikan dan

${ }^{13}$ Hasil angket dan wawancara penulis dengan guru mata pelajaran Pendidikan Agama Islam SMP Negeri 3 Yogyakarta.Pada tanggal 22 Maret 2014

LITERASI, Volume V, No. 2 Desember 2014 
pembelajaran merupakan suatu usaha untuk mendewasakan anak, terutama dalam lingkungan keluarga. Peran kedua orang tua terhadap proses belajar anak dan perkembangannya, proses pembiasaan anak dalam kehidupan sehari-hari, kiat orangtua terhadap pendidikan anak terutama dalam Pendidikan Agama Islam anak dan keteladanan yang diberikan oleh orang tua terhadap pelajaran Pendidikan Agama Islam. Peran orang tua merupakan tanggung jawab besar atas pendidikan anak, baik yang berkenaan dengan iman, moral, mental, jasmani maupun rohani.

Orang tua sebagai pendidik

Mengajarkan dan membiasakan anak mengucapkan salam

Tabel 2. Orang tua sebagai pendidik

\begin{tabular}{ccccccc}
\hline No. Item & Jawaban & Jumlah & Prosentase & Skor & Total & Rata-rata \\
\hline \multicolumn{6}{c}{ Orang tua/wali membiasakan dan mengajarkan anak mengucapkan salam di rumah setiap } \\
\cline { 3 - 6 } & Selalu & 36 & $63,2 \%$ & 4 & 144 & \\
2 & Sering & 11 & $19,3 \%$ & 3 & 33 & \\
& Kadang-kadang & 8 & $14 \%$ & 2 & 16 & $\mathbf{3 , 4 2}$ \\
& Jarang & 2 & $3,5 \%$ & 1 & 2 & \\
& Prosentase & $\mathbf{5 7}$ & $\mathbf{1 0 0} \%$ & & $\mathbf{1 9 5}$ & \\
\hline
\end{tabular}

Tabel 2. menyatakan bahwa dengan rata-rata skor 3,42, orang tua/wali siswa selalu membiasakan dan mengajarkan anak untuk mengucapkan salam, terutama ketika akan keluar/masuk ke dalam rumah atau ketika akan bepergian keluar rumah. Sebanyak 36 dari 57 responden menyatakan bahwa mereka selalu membiasakan anak-anak mereka untuk berperilaku baik, seperti mengucapkan salam ketika akan bepergian keluar rumah ataupun ketika mereka kembali ke rumah. Tidak hanya mengajarkan kepada anak saja orang tua pun membiasakan dirinya untuk ikut melaksanakannya, sebagai teladan dan contoh bagi anak-anaknya, sehingga anak juga melakukan hal yang sama seperti orang tua mereka lakukan.

Tetapi kebiasaan anak di rumah untuk mengucapkan salam disetiap akan masuk dan keluar rumah atau bepergian tidak dapat di praktikkan dengan baik di sekolah, mungkin karena anak malu jika harus disetiap saat mengucapkan salam. Anak hanya akan mengucapkan salam ketika berpamitan dengan orang tua atau keluarga yang mengantarkannya ke sekolah saja atau menjawab salam teman atau guru. Bertolak belakang dari apa yang telah diajarkan dan dibiasakan orang tua, guru disekolah bertugas untuk membimbing dan mengawasi anakanak agar dapat membiasakan hal baik yang telah diajarkan oleh orang tua mereka di rumah. 
Orang tua mengajarkan dan membiasakan anak untuk membaca do'a

Tabel 3. Orang tua sebagai pendidik

\begin{tabular}{|c|c|c|c|c|c|c|}
\hline No. Item & Jawaban & Jumlah & Prosentase & Skor & Total & Rata-rata \\
\hline \multicolumn{7}{|c|}{ Orang tua/wali membiasakan dan mengajarkan anak membaca do’a } \\
\hline \multirow{5}{*}{7} & Selalu & 37 & $64,9 \%$ & 4 & 148 & \multirow{5}{*}{3,49} \\
\hline & Sering & 11 & $19,3 \%$ & 3 & 33 & \\
\hline & Kadang-kadang & 9 & $15,8 \%$ & 2 & 18 & \\
\hline & Jarang & 0 & 0 & 1 & 0 & \\
\hline & Prosentase & 57 & $100 \%$ & & 199 & \\
\hline
\end{tabular}

Menurut tabel 3, dengan rata-rata 3,49 orang tua/wali selalu membiasakan dan mengajarkan anak untuk membaca do'a disetiap akan memulai kegiatan dan setelah selesai melaksanakan suatu pekerjaan, baik pekerjaan yang berkaitan dengan ibadah maupun kegiatan sehari-hari. Sejak kecil para orang tua mengajarkan anak-anak mereka untuk menghafal do'a-do'a harian, ketika mereka tumbuh dewasa orang tua selalu mengingatkan kepada anak-anaknya untuk terlebih dahulu membaca do'a, seperti ketika akan makan dan selesai makan, berdo'a ketika akan belajar dan selesai belajar, membiasakan untuk berdoa' ketika akan tidur dan bangun tidur. Serta do'a-do'a harian yang lainnya.

Membiasakan anak untuk selalu membaca do'a disetiap akan melakukan pekerjaan juga dibiasakan dan diajarkan di sekolah. Di sekolah anak membaca do'a terlebih dahulu setiap akan memulai pelajaran pertama dan membaca do'a juga diakhir belajar yaitu pada jam pelajaran terakhir.

Untuk do'a-do'a harian ternyata tidak banyak anak yang mengahafal dan mempraktikknya di sekolah.Apalagi jika anak sudah masuk pada kelas VIII dan IX, karena di sekolah tidak diawasi maka anak sering lupa untuk membacanya. Walaupun sebenarnya di rumah mereka dapat ingat untuk membacanya, karena ketika berada di rumah, orang tua lah yang akan mengawasi dan bertanggung jawab atas segala aktivitas anaknya.

Orang tua mengajarkan dan membiasakan anak untuk melaksanakan shalat wajib Tabel 4. Orang tua Sebagai Pendidik

\begin{tabular}{ccccccc}
\hline No.Item & Jawaban & Jumlah & Prosentase & Skor & Total & Rata-rata \\
\hline \multirow{6}{*}{12} & Orang tua/wali membiasakan & dan & mengajarkan & anak shalat wajib & & \\
& Selalu & 49 & $86 \%$ & 4 & 196 & \\
& Sering & 4 & $7 \%$ & 3 & 12 & \\
& Kadang-kadang & 4 & $7 \%$ & 2 & 8 & $\mathbf{3 , 7 8}$ \\
& Jarang & 0 & 0 & 1 & 0 & \\
& Prosentase & $\mathbf{5 7}$ & $\mathbf{1 0 0} \%$ & & $\mathbf{2 1 6}$ & \\
\hline
\end{tabular}


Berdasarkan tabel 4, sebanyak 49 responden menjawab selalu, 4 responden menjawab sering, 4 responden menjawab kadang-kadang dengan rata-rata sebanyak 3,78. Maka dapat diambil kesimpulan bahwa orang tua/ wali siswa selalu membiasakan dan mengajarkan anak untuk melaksanakan kewajibannya melaksanakan shalat, terutama shalat wajib 5 waktu.Orang tua mengajarkan anaknya untuk shalat sejak kecil, dan membiasakan serta mengingatkan anak-anaknya untuk melaksanakan shalat 5 waktu dan tidak menunda-nunda untuk melaksanakannya.

Dalam pelaksaaan shalat wajib, di sekolah sudah ada kegiatan shalat Dhuhur berjamaah yang dilaksanakan pada saat jam istirahat ke dua yang bersamaan dengan waktu Dhuhur.Tetapi masih banyak anak yang lebih memilih melaksanakan shalat Dhuhur di rumah.Siswa yang lebih banyak adalah siswa siswi kelas VII yang rajin melaksanakan shslat Duhur berjamaah di sekolah. Dengan dibantu beberapa guru anggota ROISH SMP Negeri 3 Yogyakarta untuk mengkoordinir pelaksanaan ibadah di sekolah. Karena keterbatasan ruang beribadah, maka beberapa kali jamaah shalat Dhuhur dilaksanakan 2 kali sesuai dengan banyaknya siswa siswi yang akan melaksanakan jamaah shalat Dhuhur di sekolah, terutama pada saat bulan Ramadhan tiba.

Orang tua mengajarkan dan membiasakan anak mengucapkan kata-kata baik dan sopan

Tabel 5. Orang tua sebagai pendidik

\begin{tabular}{|c|c|c|c|c|c|c|}
\hline No. Item & Jawaban & Jumlah & Prosentase & Skor & Total & Rata-rata \\
\hline \multicolumn{7}{|c|}{$\begin{array}{l}\text { Orang tua/wali membiasakan dan mengajarkan anak mengucapkan kata-kata baik dan } \\
\text { sopan dalam kehidupan sehari-hari }\end{array}$} \\
\hline \multirow{6}{*}{8} & Selalu & 51 & $89,5 \%$ & 4 & 204 & \multirow{5}{*}{3,84} \\
\hline & Sering & 5 & $8,8 \%$ & 3 & 15 & \\
\hline & Kadang-kadang & 0 & 0 & 2 & 0 & \\
\hline & Jarang & 0 & 0 & 1 & 0 & \\
\hline & Tidak menjawab & 1 & $1,7 \%$ & 0 & 0 & \\
\hline & Prosentase & 57 & $100 \%$ & & 219 & \\
\hline
\end{tabular}

Berdasarkan tabel diatas, sebanyak 51 responden menjawab selalu, 5 responden menjawab sering, dan 1 reponden tidak menjawab dengan rata-rata sebanyak 3,84, maka dapat diambil kesimpulan bahwa orang tua/wali siswa selalu membiasakan dan mengajarkan anak-anaknya untuk mengucapkan kata-kata baik dan sopan dalam kehidupan sehari-hari, di lingkungan sekolah maupun disaat berada di rumah baik dengan orang tua, guru ataupun orang yang lebih muda. 
Beberapa anak ada yang belum bisa mengkontrol kata-katanya dengan baik karena pengaruh lingkungan yang tidak mendapat pengawasan yang maksimal, baik itu di sekolah maupun di rumah. Karena kurangnya pengawasan dari pihak sekolah, maka jika memang ada yang terang-terangan ketahuan maka akan mendapat teguran dari guru. Sebagai pembelajaran dan pembiasaan berkata-kata baik di sekolah. Sebagai pembelajaran bagi siswa siswi untuk dapat bertutur kata baik dan sopan maka pihak sekolah akan memberikan pelajaran dan teguran dengan menempelkan beberapa slogan yang dapat mereka baca sebagai pelajaran untuk dapat bertutur kata dan bersikap lebih baik.

Orang tua memberikan perhatian

Orang tua memantau dan mengawasi pergaulan anak-anaknya ketika berada di rumab dan bersama dengan teman-temannya

Tabel 6. Orang tua Memberikan Perhatian

\begin{tabular}{|c|c|c|c|c|c|c|}
\hline No. Item & Jawaban & Jumlah & Prosentase & Skor & Total & Rata-rata \\
\hline \multicolumn{7}{|c|}{ Orang tua/wali memperhatikan pergaulan anak dengan teman-temannya } \\
\hline \multirow{6}{*}{11} & Selalu & 39 & $68,4 \%$ & 4 & 156 & \multirow{5}{*}{3,54} \\
\hline & Sering & 14 & $24,6 \%$ & 3 & 42 & \\
\hline & Kadang-kadang & 2 & $3,5 \%$ & 2 & 4 & \\
\hline & Jarang & 0 & $0 \%$ & 1 & 0 & \\
\hline & Tidak menjawab & 2 & 3,50 & 0 & 0 & \\
\hline & Prosentase & 57 & $100 \%$ & & 202 & \\
\hline
\end{tabular}

Hasil dari tabel 6 menyatakan rata-rata sebanyak 3,54orang tua selalu memperhatikan pergaulan anak dengan teman-temannya baik di sekolah maupun di rumah. Orang tua mengetahui siapa saja teman bermain anakanaknya, kemana saja mereka sering bermain dan kegiatan-kegiatan apa yang sering mereka lakukan. Hal ini sebagai kontrol kepada anak-anak agar tidak salah memilih teman bergaul.

Bentuk perhatian yang diberikan orang tua berkaitan enggan pengendalian diri anak dan pengawasan terhadap anak adalah masih banyaknya orang tua yang mengantar jemput anak-anaknya dan beberapa kali bertanya tentang teman bergaul mereka, agar orang tua juga mengenal teman dekat anak-anak mereka. 


\section{Orang tua memahami tingkab laku anak}

Tabel 7. Orang tua Memberikan Perhatian

\begin{tabular}{|c|c|c|c|c|c|c|}
\hline No. Item & Jawaban & Jumlah & Prosentase & Skor & Total & Rata-rata \\
\hline \multicolumn{7}{|c|}{ Orang tua/wali memahami tingkah laku anak di rumah } \\
\hline \multirow{5}{*}{15} & Selalu & 38 & $66,7 \%$ & 4 & 152 & \multirow{5}{*}{3,63} \\
\hline & Sering & 17 & $29,8 \%$ & 3 & 51 & \\
\hline & Kadang-kadang & 2 & $3,5 \%$ & 2 & 4 & \\
\hline & Jarang & 0 & 0 & 1 & 0 & \\
\hline & Prosentase & 57 & $100 \%$ & & 207 & \\
\hline
\end{tabular}

Dari tabel 7 menyatakan bahwa rata-rata sebanyak 3,63, berarti bahwa orang tuadapat memahami dan selalu memperhatikan tingkah laku anak di rumah.Sebanyak 38 orang tua/wali siswa menjawab selalu memperhatikan tingkah laku anak, jadi ketika ada sikap anak yang tidak seperti biasa, orang tua dengan cepat memahami dan menindaklanjuti, agar perubahan sikap anak, terutama perubahan yang cenderung kearah yang negatif dapat dengan cepat diatasi dan mencari solusi serta jalan keluar yang tepat. Dari hasil pengisian angket diatas, maka dapat di ambil kesimpulan bahwa dalam proses pemberian bekal pengetahuan Pendidikan Agama Islam, orang tua memberikan perhatian yang maksimal kepada Pendidikan Agama Islam anak.

Orang tua sebagai teladan

Orang tua mengajak anak untuk melaksanakan shalat di masjid/mushalla

Tabel 8. Orang tua Sebagai Teladan

\begin{tabular}{ccccccc}
\hline No. Item & Jawaban & Jumlah & Prosentase & Skor & Total & Rata-rata \\
\hline \multirow{5}{*}{3} & Orang tua/wali mengajak & anak & untuk shalat & di masjid & mushalla & \\
& Selalu & 21 & $36,9 \%$ & 4 & 84 & \\
& Sering & 12 & $21,1 \%$ & 3 & 36 & \\
& Kadang-kadang & 19 & $33,3 \%$ & 2 & 38 & $\mathbf{2 , 8 4}$ \\
& Jarang & 4 & $7 \%$ & 1 & 4 & \\
& Tidak menjawab & 1 & $1,7 \%$ & 0 & 0 & \\
& Prosentase & $\mathbf{5 7}$ & $\mathbf{1 0 0} \%$ & & $\mathbf{1 6 2}$ & \\
\hline
\end{tabular}

Pada tabel 8 dengan rata-rata sebanyak 2,84, orang tua/wali siswa sering mengajak anak-anaknya untuk melaksanakan kewajiban shalatnya di masjid/di mushalla yang berdekatan dengan tempat tinggal. Karena dengan mengajaknya untuk melaksanakan shalat di masjid dapat meminimalisir anak untuk tidak melaksanakan shalat.Dan melatih kedisiplinan anak untuk melaksanakan shalat tepat pada waktunya. Berdasarkan tabel diatas, sebanyak 21 responden 
menjawab selalu, 12 responden menjawab sering, 19 responden menjawab kadang-kadang, 24 respoden menjawab jarang dan 1 reponden tidak menjawab dengan rata-rata sebanyak 2,84. Maka dapat diambil kesimpulan bahwa orang tua/wali siswa sering mengajak anak-anaknya untuk melaksanakan shalat di masjid/di mushalla.

Beberapa anak biasa diajak oleh orang tua mereka untuk melaksanakan shalat jamaah di masjid/mushalla terdekat.Hasil wawancara penulis dengan beberapa siswa siswi SMP Negeri 3 Yogyakarta menunjukkan hasil bahwa, beberapa dari mereka sering melaksanakan shalat berjamaah di masjid/ mushalla yang lokasinya dekat dengan tempat tinggal mereka. Hal ini selaras dengan hasil angket yang telah disebarkan penulis dengan beberapa orang tua wali siswa, yaitu dengan rata-rata 2,84 orang tua mengajak anak-anak mereka untuk berjamaah di masjid/ mushalla.

\section{Orang tua memberikan teladan yang baik kepada anak}

\section{Tabel 9. Orang tua Sebagai Teladan}

\begin{tabular}{|c|c|c|c|c|c|c|}
\hline No. Item & Jawaban & Jumlah & Prosentase & Skor & Total & Rata-rata \\
\hline \multicolumn{7}{|c|}{ Orang tua/wali memberikan contoh keteladanan yang baik kepada anak } \\
\hline \multirow{6}{*}{6} & Selalu & 41 & $71,9 \%$ & 4 & 164 & \multirow{5}{*}{3,57} \\
\hline & Sering & 12 & $21,1 \%$ & 3 & 36 & \\
\hline & Kadang-kadang & 2 & $3,5 \%$ & 2 & 4 & \\
\hline & Jarang & 0 & 0 & 1 & 0 & \\
\hline & Tidak menjawab & 2 & $3,5 \%$ & 0 & 0 & \\
\hline & Prosentase & 57 & $100 \%$ & & 204 & \\
\hline
\end{tabular}

Berdasarkan tabel diatas, sebanyak 41 responden menjawab selalu, 12 responden menjawab sering, 2 responden menjawab kadang-kadang, dan 2 reponden tidak menjawab dengan rata-rata 3,57. Maka dapat diambil kesimpulan bahwa orang tua/wali siswa selalu memberikan contoh keteladanan yang baik kepada anak, dengan cara orangtua rajin melaksanakan ibadah agar dapat dicontoh anak-anaknya, selalu bertutur kata baik dan berperilaku baik dan sopan kepada siapa saja, dapat menahan amarah dihadapan anak. 
Orang tua berusaba menjaubkan diri dari perbuatan buruk dan tercela

Tabel 10. Orang tua Sebagai Teladan

\begin{tabular}{|c|c|c|c|c|c|c|}
\hline No. Item & Jawaban & Jumlah & Prosentase & Skor & Total & Rata-rata \\
\hline \multicolumn{7}{|c|}{ Orang tua/wali berusaha menjauhkan diri dari perbuatan buruk dan tercela } \\
\hline \multirow{6}{*}{17} & Selalu & 44 & $77,2 \%$ & 4 & 176 & \multirow{5}{*}{3,71} \\
\hline & Sering & 12 & $21,1 \%$ & 3 & 36 & \\
\hline & Kadang-kadang & 0 & 0 & 2 & 0 & \\
\hline & Jarang & 0 & 0 & 1 & 0 & \\
\hline & Tidak menjawab & 1 & $1,7 \%$ & 0 & 0 & \\
\hline & Prosentase & 57 & $100 \%$ & & 212 & \\
\hline
\end{tabular}

Berdasarkan tabel diatas, sebanyak 44 responden menjawab selalu, 12 responden menjawab sering, dan 1 reponden tidak menjawab dengan ratarata 3,71.Maka dapat diambil kesimpulan bahwa orang tua/wali siswa selalu berusaha menjauhan diri dari perbuatan buruk karena dapat berpengaruh pada kebiasaan dan perkembangan anak.

Dari wawancara penulis dengan beberapa anak, menyatakan bahwa orang tua mereka di rumah juga menjaga sikap dan tidak bertindak kasar dan keras bila berada dihadapan anak.Perilaku seperti itu dijadikan contoh bagi anakanak untuk selalu bersikap baik dan sopan kepada siapa saja dan dimana saja. ${ }^{14}$

Orang tua memberikan contob keteladanan yang berpengarub positif kepada anak

Tabel 11. Orang tua Sebagai Keteladanan

\begin{tabular}{ccccccc}
\hline No. Item & Jawaban & Jumlah & Prosentase & Skor & Total & Rata-rata \\
\hline \multicolumn{6}{c}{ Keteladanan yang dicontohkan } & memberikan pengaruh yang positif terhadap anak \\
\cline { 3 - 6 } & Selalu & 35 & $61,4 \%$ & 4 & 140 & \\
Sering & 15 & $26,3 \%$ & 3 & 45 & \\
& Kadang-kadang & 5 & $8,8 \%$ & 2 & 10 & $\mathbf{3 , 4 2}$ \\
& Jarang & 0 & 0 & 1 & 0 & \\
& Tidak menjawab & 2 & $3,5 \%$ & 0 & 0 & \\
& Prosentase & $\mathbf{5 7}$ & $\mathbf{1 0 0} \%$ & & $\mathbf{1 9 5}$ & \\
\hline
\end{tabular}

Berdasarkan tabel diatas, sebanyak 35 responden menjawab selalu, 15 responden menjawab sering, 5 responden menjawab kadang-kadang, dan 1 reponden tidak menjawab dengan rata-rata 3,42. Maka dapat diambil kesimpulan bahwa orang tua/wali siswa sering melihat bahwa keteladanan

${ }^{14}$ Hasil wawancara penulis dengan beberapa siswa SMP Negeri 3 Yogyakarta pada tanggal 10 Maret 2013 
yang dicontohkan orang tua dapat memberikan pengaruh yang positif pada diri anak-anaknya

Contoh keteladanan yang dicontoh anak dari orang tua menurut wawancara yang telah dilakukan oleh penulis dengan beberapa siswa siswi SMP Negeri 3 Yogyakarta adalah kebiasaan baik bersikap dan berkata sopan, orang tua mengajarkan dan mengajak anak-anak untuk melaksanakan shalat dengan tertib dan khusyuk. Beberapa orang tua juga mengajak anak-anaknya untuk melaksanakan beberapa ibadah sunnah, seperti shalat Dhuha dan tahajud. Contoh keteladanan yang paling banyak dicontoh anak adalah dari segi sikap dan perilaku orang tua yang sopan dan santun serta selalu bersikap baik dengan siapa saja dan dimana saja, tidak berprasangka buruk dan tidak mudah putus asa. Beberapa point yang dicontoh anak merupakan gambaran dari sikap orang tua yang memperhatikan anak-anaknya agar menjadi pribadi yang lebih baik dimasyarakat. ${ }^{15}$

Metode dan cara-cara yang dapat ditempuh oleh orangtua dalam proses Pendidikan Agama Islam yang didapat penulis dari hasil wawancara dengan beberapa orangtua/wali siswa adalah

a. Orangtua memberikan tauladan yang baik kepada anak, dengan selalu bersikap baik dan santun ketika berada dirumah

b. Menahan amarah ketika tertimpa masalah dihadapan anak, hal ini dilakukan beberapa orangtua agar tidak mengganggu aktifitas belajar anak

c. Orang tua membiasakan untuk selalu melaksanakan shalat tepat pada waktunya, walaupun beberapa dari mereka sibuk dengan pekerjaannya

d. Menyiapkan perlengkapan ibadah anak, baik saat akan melaksanakan shalat maupun mengaji

e. Membiasakan untuk berkumpul dengan anggota keluarga, agar lebih dekat dengan anak dan secara tidak langsung menanyakan perkembangan sekolah mereka dan bertanya mengenai pendidikan agama

f. Membiasakan diri berpamitan ketika anak berangkat sekolah atau pergi keluar rumah, mencium kedua tangan orangtua dan mengucapkan salam ${ }^{16}$

Berdasarkan hasil angket yang telah disebarkan penulis dengan orang tua siswa siswi SMP Negeri 3 Yogyakarta dapat dilihat kembali pada tabel dibawah ini:

${ }^{15}$ Hasil wawancara penulis dengan beberapa siswa SMP Negeri 3 Yogyakarta pada tanggal 10 Maret 2013

${ }^{16}$ Hasil wawancara penulis dengan beberapa orangtua siswa SMP Negeri 3 Yogyakarta pada tanggal 10 Maret, 11 Maret dan 12 Maret 2014

LITERASI, Volume V, No. 2 Desember 2014 
Tabel 12. Hasil Angket Penelitian Orang tua

\begin{tabular}{cccccccccc}
\hline Jawaban & $\mathbf{1}$ & $\mathbf{2}$ & $\mathbf{3}$ & $\mathbf{4}$ & $\mathbf{5}$ & $\mathbf{6}$ & $\mathbf{7}$ & $\mathbf{8}$ & $\mathbf{9}$ \\
\hline Selalu & 36 & 144 & 84 & 36 & 192 & 164 & 148 & 204 & 64 \\
Sering & 66 & 33 & 36 & 36 & 15 & 36 & 33 & 15 & 42 \\
Kadang & 50 & 16 & 38 & 28 & 6 & 4 & 18 & 0 & 28 \\
Jarang & 1 & 2 & 4 & 21 & 0 & 0 & 0 & 0 & 10 \\
\hline & & & & & & & & & \\
\hline Jawaban & $\mathbf{1 0}$ & $\mathbf{1 1}$ & $\mathbf{1 2}$ & $\mathbf{1 3}$ & $\mathbf{1 4}$ & $\mathbf{1 5}$ & $\mathbf{1 6}$ & $\mathbf{1 7}$ & $\mathbf{1 8}$ \\
\hline Selalu & 36 & 156 & 196 & 32 & 84 & 152 & 140 & 176 & 16 \\
Sering & 45 & 42 & 12 & 63 & 54 & 51 & 45 & 36 & 48 \\
Kadang & 28 & 4 & 8 & 40 & 28 & 4 & 10 & 0 & 34 \\
Jarang & 6 & 0 & 0 & 7 & 3 & 0 & 0 & 0 & 7 \\
\hline
\end{tabular}

\begin{tabular}{ccccc}
\hline $\mathbf{1 9}$ & Jml & Total & Jml Responden & \% \\
\hline 116 & 2176 & & & \\
29 & 737 & & & \\
24 & 368 & $\mathbf{3 3 5 4}$ & $\mathbf{5 7}$ & $\mathbf{7 7 , 4 2 \%}$ \\
2 & 63 & & & \\
\hline
\end{tabular}

Dari hasil angket yang telah penulis bagi kepada beberapa wali siswa dapat diambil kesimpulan bahwa sebanyak $77,42 \%$ orang tua /wali siswa memperhatikan proses belajar dan perkembangannya, pembiasaan anak dalam kehidupan sehari-hari, memiliki kiat-kiat khusus agar anak dapat melaksanakan ibadah secara baik dan tepat pada waktunya serta orangtua/wali memberikan teladan yang baik kepada anak di rumah. Kesimpulannya adalah para orang tua/wali siswa SMP Negeri 3 Yogyakarta memberikan perhatian dan dukungan Pendidikan Agama Islam anak dengan baik, sesuai dengan kehidupan seharihari yang dapat diaplikasikan kedalam perilaku dan sikap sehari-hari baik di sekolah, di masyarakat maupun di rumah.

\section{Hubungan Sekolab dengan Orang tua dalam Proses Pembelajaran Pendidikan Agama Islam Siswa SMP Negeri 3 Yogyakarta}

Berdasarkan hasil penelitian yang telah dlakukan oleh penulis menunjukkan bahwa hubungan sekolah dan keluarga dalam proses pembelajaran Pendidikan Agama Islam terjalin sangat baik dan harmonis. Hubungan yang terjalin antara sekolah dan keluarga dihubungkan dengan kegiatan-kegiatan yang telah dilaksanakan.kegiatan-kegiatan yang telah dilakukan sekolah dalam proses menjalin silaturahmi dan kerjasama dengan para orang tua siswa adalah sebagai berikut : 
a. Adanya pertemuan dengan orangtua/wali pada hari penerimaan rapor. Dalam pertemuan yang dilaksanakan bersamaan dengan pembagian rapor siswa diharapakan dapat menjadi tempat bagi guru untuk menjelaskan prestasi akademik anak kepada orang tua, sebagai bahan evaluasi siswa selama belajar pada kelas yang ditempati siswa. Dalam kegiatan pembagian rapor ini juga bertujuan untuk menjalin silaturahmi guru, khususnya wali kelas dengan orang tua, selain itu pada pembagian rapor seperti ini juga orang tua banyak yang akan menanyakan perihal prestasi dan kendala apa saja yang dihadapi siswa selama belajar.

b. Pengadaan pertemuan pada saat penerimaan siswa baru

Dalam pertemuan yang diadakan sekolah dengan orang tua siswa baru dimaksudkan untuk memperkenalkan profil sekolah lebih dalam kepada orang tua dan masyarakat, agar orang tua mengetahui banyak informasi-informasi berkaitan dengan proses belajar mengajar dan kegiatan apa saja yang diadakan dan dilaksanakan di SMP Negeri 3 Yogyakarta.

a. Adanya daftar nilai rapor atau nilai ulangan sebagai informasi kepada orang tua/wali siswa berkaitan dengan nilai akademik pada setiap mata pelajaran/ ekstrakurikuler yang diadakan sekolah.

b. Kunjungan guru ke rumah orang tua atau kunjungan orangtua ke sekolah untuk membicarakan perkembangan belajar siswa maupun menyelesaikan permasalahan yang dihadapi siswa di sekolah maupun di rumah

c. Mengadakan pesta perayaan ulang tahun sekolah

d. Pengajian wali murid yang diadakan secara bergiliran sesuai dengan kesepakatan dan hasil musyawarah bersama wali murid

Kegiatan-kegiatan yang dilakukan pihak sekolah di atas selain sebagai bentuk dari silaturahmi dengan orang tua juga sebagai wujud perhatian terhadap siswa dan anak untuk memantau perkembangan akademik maupun non akademik siswa dan anak. Salah satu kegiatan sekolah dan orangtua/ keluarga siswa siswi SMP Negeri 3 Yogyakarta dalam segi keagamaan, yaitu pengajian wali murid yang diadakan secara bergilir, dalam kegiatan ini baru diadakan satu kali yaitu pada kelas VII, karena kesibukan para orang tua dan keluarga, kegiatan ini belum dapat terlaksanan dengan baik. Begitu pula kegiatan pengajian guru dan orang tua, karena keterbatasan waktu guru dan orang tua, kegiatan ini belum bisa terlaksana, tetapi sudah menjadi agenda kegiatan di SMP Negeri 3 dan akan dilaksanakan diwaktu-waktu tertentu sebagai wujud perhatian sekolah dan orang tua dalam bidang keagamaan dan sebagai wujud silaturahmi keduanya. 
Menurut hasil wawancara dengan Kepala SMP Negeri 3 Yogyakarta, hubungan antara sekolah dan wali siswa-siswi SMP Negeri 3 Yogyakarta terjalin sangat harmonis dalam rangka mendukung proses belajar mengajar di sekolah maupun di rumah.Dengan diadakannya pertemuan pada saat penerimaan rapor siswa, guru wali kelas dapat memberikan informasi berkaitan perkembangan siswa kepada orang tua dan dapat membantu orangtua dalam menjalankan tugasnya sebagai pendidik di rumah. Terkait dengan kunjungan pihak sekolah ke rumah siswa, biasa dilakukan oleh guru BK kepada siswa-siswi yang bermasalah dalam bidang akademik maupun non akademik yang tidak dapat diselesaikan atau ditangani sendiri oleh pihak sekolah. Perlu bantuan dan dukungan dari orang tua agar permasalahan anak dapat terselesaikan. Kegiatan seperti ini sering kali dilakukan oleh pihak sekolah, terakhir kunjungan adalah pada minggu lalu (pada bulan Maret), kepada salah satu orang tua siswa karena siswa yang bersangkutan bermasalah di sekolah. ${ }^{17}$

\section{Pembahasan}

Hasil penelitian menunjukkan bahwa ada peran bersama antara sekolah dan orang tua dalam proses pendidikan anak, khususnya pada Pendidikan Agama Islam Siswa SMP Negeri 3 Yogyakarta. Berdasarkan hasil penelitian kerjasama diantara sekolah dan orang tua terjalin sangat baik dan harmonis. Begitu pula dengan peran sekolah terhadap proses pembelajaran dan peningkatan Pendidikan Agama Islam siswa dari segi akademik maupun non akademik. Kegiatan-kegiatan keagamaan yang dilaksanakan di SMP Negeri 3 Yogyakarta sangatlah beragam untuk membantu meningkatkan mutu dan kualitas Pendidikan Agama Islam pada diri peserta didik. Hal ini dengan diadakannya beberapa kegiatan keagamaan yaitu 1) pelaksanaan shalat Dhuha, Dhuhur dan shalat Jum'at di sekolah, 2) kajian Islami bagi siswa SMP Negeri 3 Yogyakarta pada hari Jum'at bersamaan dengan pelaksanaan shalat Jum'at bagi siswa, 3) pengadaan Infaq setiap hari Jum'at 4) pelaksanaan bakti sosial dan zakat kepada masyarakat sekitar SMP Negeri 3 Yogyakarta, 5) pengajian memperingati Hari Besar Islam dan 6) keikutsertaan dan pengadaan lomba keagamaan tingkat daerah maupun Nasional.

Selain sekolah yang berperan bagi pendidikan siswa siswinya, guru adalah orang yang paling bertanggung jawab terhadap pendidikan siswa siswinya. Peran dan tanggung jawab guru dalam pendidikan sangat besar. Apalagi dalam konteks Pendidikan Agama Islam, semua aspek kependidikan dalam

${ }^{17}$ Hasil wawancara penulis dengan kepala SMP Negeri 3 Yogyakarta di ruang Kepala Sekolah SMP Negeri 3 Yogyakarta [pada tanggal 22 Maret 2014 
Islam terkait dengan nilai-nilai yang melihat guru bukan saja pada penugasan material pengetahuan, tetapi juga pada investasi nilai-nilai moral dan spiritual yang diembannya untuk mentransformasikan kearah pembentukan kepribadian Islam, guru dituntut bagaimana membimbing, melatih dan membiasakan anak didik berperilaku yang baik. Karena itu eksistensi guru tidak saja mengajarkan tetapi sekaligus mempraktikkan ajaran-ajaran dan nilai-nilai kependidikan Islam. $^{18}$

Menurut Dakir, perhatian adalah keaktifan peningkatan seluruh fungsi jiwa yang dikerahkan dalam pemusatannya kepada barang sesuatu, baik yang ada didalam maupun diluar diri kita. ${ }^{1}$ Perhatian yang diberikan oleh sekolah dan orang tua bertujuan untuk mengontrol perilaku dan sikap siswa serta sebagai bentuk dukungan yang diberikan kepada siswa. Perhatian yang diberikan oleh sekolah dan orang tua sangat berpengaruh terhadap motivasi siswa dalam proses belajar. Perhatian-perhatian yang diberikan oleh orang tua di rumah meliputi perhatian orang tua terhadap pergaulan anak dengan teman-temannya. Dari hasil penelitian sebanyak $77,42 \%$ orang tua memahami dan memperhatikan benar pergaulan anak dengan teman-temannya. Perhatian orang tua terhadap kebiasaan anak dalam kegiatan sehari-hari, seperti membiasakan anak untuk mengucapkan salam, membaca do'a disetiap akan memulai aktifitasnya, perhatian orangtua terhadap pelaksanaan ibadah anak, dan perrilaku berbuat baik dan santun disetiap kegiatan.

Dengan kondisi tersebut dapat diambil kesimpulan bahwa siswa SMP Negeri 3 Yogyakarta mendapatkan perhatian yang besar dan dukungan dari orang tua.Peran orang tua sebagai pendidik utama dalam keluarga juga berpengaruh terhadap pendidiakan anak disekolah.Hal ini ditunjukkan dengan hasil dari pengisian angket yang telah diisi oleh 57 orang tua/wali siswa SMP Negeri 3 Yogyakarta.Bahwa peran orang tua sangat diperlukan anak untuk menunjang prestasi akademik di sekolahnya, khususnya pada mata pelajaran Pendidikan Agama Islam. Menurut hasil angket sebanyak 77,42\%orang tua/ wali siswa memberikan perhatiannya dan dukungan kepada anak dalam hal perhatian kepada proses belajar anak dan perkembangnnya, baik di rumah maupun di sekolah, pembiasaan anak untuk berperilaku baik dan melaksanakan ibadah tepat pada waktunya yang sesuai dengan kehidupan sehari-hari, para orang tua memiliki kiat khusus untuk mendorong anaknya rajin melaksanakan ibadah dan berakhlak baik setiap hari serta orang tua menjadi teladan atau panutan anak-anaknya. Apabila orang tua berbuat dan berperilaku baik maka

\footnotetext{
${ }^{18}$ Abd.Aziz, Filsafat Pendidikan Islam ....., hlm. 182

${ }^{19}$ Dakir, Dasar-dasar Psikologi ....., hlm. 8
} 
akan dicontoh oleh anak-anak mereka, apabila anak berperilaku buruk bisa jadi adalah bentuk cerminan orang tua ketika berada di rumah.

Menurut Hamid Abdul Khaliq Hamid, bentuk perhatian orang tua kaitannya dengan Pendidikan Agama Islam bagi anak adalah mengarahkan memilih teman bergaul dengan anak-anak mengajak makan bersama anggota keluarga, mengontrol bacaan anak, kebiasaan menemani anak belajar, mengontrol kegiatan anak, membiasakan shalat berjamaah dengan anggota keluarga, membiasakan anak untuk membaca Al-Qur'an, membiasakan anak mengerjakan pekerjaan rumah. ${ }^{20}$

Selaras dengan teori yang dikemukakan oleh Hamid Abdul Khaliq Hamid, perhatian yang diberikan orang tua di rumah kepada anak.

Orang tua adalah pendidik yang terutama dan utama yang sudah semestinya.Mereka pendidik asli, yang menerima tugas dan kodrat dari Tuhan untuk mendidik anak-anaknya. ${ }^{21} \mathrm{Hal}$ ini sesuai dengan tanggung jawab orangtua/wali siswa SMP Negeri 3 Yogyakarta.Orang tua adalah pendidik utama bagi anak, karena hal dasar yang diperoleh anak berasal dari pendidikan yang diberikan oleh orang tua. Contohnya adalah orang tua mengajarkan dan membiasakan mengucapkan salam ketika berada di rumah, orang tua mengajarkan dan membiasakan anak untuk membaca do'a disetiap akan memulai aktifitas, orang tua mengajarkan anak shalat dan membiasakan anak untuk melaksanakan shalat wajib lima waktu, dan masih banyak lagi pendidikan yang diajarkan orang tua di rumah. Hal terpenting bagi anak agar dapat berperilaku baik dan melaksanakan kewajibannya dengan tepat waktu dan sesuai adalah dengan pembiasaan yang dilakukan anak.Apabila anak dibiasakan berbuat baik maka dalam kehidupan sehari-hari tanpa menunggu orang tua yang meminta maka anak telah sadar dengan sendirinya untuk melaksanakan pekerjaan tersebut.Penting bagi orang tua untuk membiasakan diri mereka masing-masing dan mengajarkannya kepada anak.

Menurut Burghardt, kebiasaan itu timbul karena proses penyusutan kecenderungan respons dengan menggunakan simulasi yang berulang-ulang. ${ }^{22}$ Kebiasan-kebiasaan baik ini yang akan mempengaruhi sikap dan perilaku anak baik di sekolah maupun di rumah.

Tidak hanya menjadi tanggung jawab orang tua saja seorang anak dapat dididik dengan baik juga berpengaruh terhadap perilaku sosial di sekolah.Kebiasaan baik yang ditunjukkan oleh semua warga sekolah juga

${ }^{20}$ Hamid Abdul Khaliq Hamid, Wabai Ibu ....., hlm. 13

${ }^{21}$ Ngalim Purwanto, Ilmu Pendidikan Teoritis ....., hlm. 49

${ }^{22}$ Haryu Islamuddin, Psikologi ....., hlm. 164 
dapat mempengaruhi sikap dan perilaku seorang anak. Penting juga pihak sekolah membuat dan menjalankan tata tertib yang sesuai dengan syariat tujuan pendidikan dan sesuai dengan pendidikan agama, karena setiap agama memiliki kesamaan dalam membentuk akhlak baik dan membentuk moral pada diri setiap anak. Agar sikap dan perilaku seorang anak dapat dikontrol dan dipantau setiap waktu.

Dengan adanya kerjasama, orang tua dapat memperoleh pengetahuan dan pengalaman dari guru dalam hal mendidik anak-anaknya. Sebaliknya, para guru dapat memperoleh keterangan-keterangan dari orangtua tentang kehidupan dan sifat-sifat anaknya. Peran antara sekolah dan orang tua sama-sama penting dalam menentukan masa depan anak, karena dengan perhatian dan pemberian bekal pengetahuan yang cukup dan sesuai berpengaruh terhadap perilaku dan kebiasaan anak di sekolah maupun di rumah.

Menurut Hasan Langgulung ada tujuh bidang pendidikan yang dapat dikembangkan oleh orang tua dalam pendidikan keluarga yaitu pendidikan jasmani, kesehatan, intelektual, agama, psikologi dan emosi, akhlak dan sosial anak. ${ }^{23}$

Sebagai pendukung bahwa pihak sekolah juga berperan penting terhadap perkembangan keagamaan siswa adalah dengan diadakannya beberapa kegiatan keagamaan di SMP Negeri 3 Yogyakarta pada saat bulan Ramadhan maupun pada kegiatan sekolah lainnya. Beberapa kegiatan tersebut adalah (1) pengadaan pertemuan dengan orang tua/wali pada saat penerimaan rapor dan penerimaan siswa baru SMP Negeri 3 Yogyakarta (2) adanya daftar nilai ujian dan ulangan serta nilai ekstrakurikuler yang diikuti siswa di sekolah (3) kunjungan guru ke rumah orang tua siswa (4) pengadaan pesta perayaan HUT SMP Negeri 3 Yogyakarta dan (5) pengajian wali murid secara bergilir.

Dengan diadakannya beberapa kegiatan yang melibatkan orang tua untuk ikut berpartisipasi dan menyukseskan program pembelajaran yang dilaksanakan sekolah.Hubungan baik yang terjalin diantara sekolah dan orang tua bertujuan untuk memantau perkembangan akademik siswa baik di sekolah maupun di rumah.Meningkatnya hasil belajar siswa tidak lepas dari tanggung jawab orang tua yang selalu memantau belajar anak di rumah, dengan mengadakan les privat sampai les pada bimbingan belajar tertentu yang tidak mengganggu jadwal sekolah anak.Dibantu dengan tenaga pendidik yang berada di sekolah, dengan menambah jam pelajaran tertentu. Hal ini menunjukkan bahwa kegiatankegiatan yang dilaksanakan di sekolah maupun di rumah mendapatkan respon baik oleh sekolah dan orang tua.

${ }^{23}$ Moh.Padil dan Iriyo Supriyatno, Sosiologi Pendidikan, (Malang : UIN Maliki Press, 2010),hlm. 139

LITERASI, Volume V, No. 2 Desember 2014 


\section{KESIMPULAN}

Berdasarkan hasil penelitian Peran Sekolah dan Orang tua dalam Pelaksanaan Pendididkan Agama Islam SMP Negeri 3 Yogyakarta Tahun Pelajaran 2013/2014 dapat diambil beberapa kesimpulan, sebagai berikut :

1. Sekolah memiliki peran dalam pelaksanaan Pendidikan Agama Islam di SMP Negeri 3 Yogyakarta, terutama dalam :

a. Pelaksanaan shalat Dhuha

b. Pelaksanaan shalat Dhuhur berjamaah

c. Pelaksanaan shalat Jum'at

d. Kajian Islami bagi siswi SMP Negeri 3 Yogyakarta yang di isi oleh relawan mahasiswa Jogja.

e. Infaq rutin setiap hari Jum'at yang dikoordinir oleh angota ROHIS SMP Negeri 3 Yogyakarta

f. Pelaksanaan kegiatan bakti sosial dan zakat

g. Pengajian memperingati hari besar Islam

h. Lomba-lomba keagamaan tingkat daerah sampai Nasional

i. Tadarus rutin

j. Pesantren kilat

2. Peran orang tua dalam pelaksanaan Pendidikan Agama Islam di SMP Negeri 3 Yogyakarta adalah :

a. Orang tua sebagai pendidik

1) Mengajarkan dan membiasakan anak mengucapkan salam

2) Mengajarkan dan membiasakan anak untuk membaca do'a

3) Mengajarkan dan membiasakan anak melaksanakan shalat wajib

4) Mengajarkan dan membiasakan anak mengucapkan kata-kata baik dan sopan

b. Orang tua memberikan perhatian

1) Orang tua memantau dan mengawasi pergaulan anak-anaknya ketika berada di rumah dan ketika bersama teman-temannya

2) Orang tua memahami tingkah laku anak

c. Orang tua sebagai teladan

1) Orang tua mengajak anak untuk melaksanakan shalat di masjid/ mushalla

2) Orang tua memberikan teladan yang baik kepada anak, dengan membiasakan melaksanakan shalat tepat waktu, mengaji dan berperilaku baik dan sopan

3) Orang tua berusaha menjauhkan diri dari perbuatan buruk dan tercela 
4) Orang tua memberikan contoh keteladanan yang berpengaruh positif kepada anak

3. Hubungan kerjasama sekolah dan orang tua dalam pelaksanaan Pendidikan Agama Islam di SMP Negeri 3 Yogyakarta adalah :

a. Pengadakan pertemuan dengan orangtua/wali pada hari penerimaan rapor dan penerimaan siswa baru atau waktu-waktu tertentu yang dirasa perlu diadakannya pertemuan

b. Adanya daftar nilai rapor atau nilai ulangan sebagai informasi kepada orangtua/wali siswa berkaitan dengan nilai akademik pada setiap mata pelajaran/ ekstrakurikuler yang diadakan sekolah

c. Kunjungan guru ke rumah orang tua atau kunjungan orang tua ke sekolah untuk membicarakan perkembangan belajar siswa maupun menyelesaikan permasalahan yang dihadapi siswa di sekolah maupun di rumah

d. Mengadakan pesta perayaan ulang tahun sekolah

e. Pengajian wali murid yang diadakan secara bergiliran sesuai dengan kesepakatan dan hasil musyawarah bersama wali murid, kegiatan ini dilaksanakan untuk mempererat silaturahmi antar wali murid dan guru yang bersangkutan.

\section{DAFTAR PUSTAKA}

Abd.Aziz. 2009.Filsafat Pendidikan Islam, Sebuab Gagasan Membangun Pendidikan Islam. Yogyakarta : Teras

Abdullah Idi. 2011. Sosiologi Pendidikan Individu, Masyarakat dan Pendidikan. Jakarta : PT Raja Grafindo Persada

Ahmad Salim. Manajemen Pendidikan Karakter madrasab, Sebuab Konsep dan Penerapannya. Yogyakarta : Sabda Media

Ahmad Tafsir. 1997. Metodologi Pengajaran Islam. Bandung : PT Remaja Rosda Karya

Badri Yatim. 2008. Sejarah Peradaban Islam Dirasab Islamiyah II. Jakarta : PT Raja Grafindo Persada

Bukhari Umar. 2010. Ilmu Pendidikan Islam. Jakarta : Amzah

E.Mulyasa. 2011.Manajemen Berbasis Sekolah. Bandung : PT Remaja Rosda Karya

Fak.Tarbiyah IAIN Walisongo Semarang. 1998. PBM-PAI di Sekolah. Eksistensi dan Proses Belajar Mengajar PAI.Yogyakarta : Pustaka Pelajar Offset 
Hamzah B Uno dan Nurdin Mohamad. 2012. Belajar dengan Pendekatan PAILKEM : Pembelajaran Aktif, Inovatif, Lingkungan, Kretif, Efektif, Menarik. Jakarta : PT Bumi Aksara

Haryu Islamuddin. 2012. Psikologi Pendidikan. Yogyakarta : Pustaka Pelajar John W. Santrock penerjemah : Diana Angelica.2009. Educational Psychology, ed 3th (Psikologi Pendidikan jilid tiga., Jakarta : Salemba Humanika

Khusna Rofiqoh. 2011. Sikap Orangtua dalam Pendidikan Agama Islam di Keluarga pada Burub Tani di Dusun Clapar Ngawen Muntilan, Yogyakarta: Skripsi Prodi PAI Fakultas Tarbiyah UIN Sunan Kalijaga Yogyakarta

Mahmud Arief. 2012. Strategi Pembelajaran Pendidikan Agama Islam di Sekolah, Teori, Metodologi dan Implementasi. Yogyakarta : Idea Press Yogyakart

Moh.Padil dan IriyoSupriyatno. 2010. Sosiologi Pendidikan.Malang : UIN Maliki Press

Ngalim Purwanto. 2009. Ilmu Pendidikan Teoretis dan Praktis.Bandung : PT Remaja Rosda Karya

Siti 'Azizah. 2009. Hubungan antara Perhatian Orangtua dengan Prestasi Belajar Pendidikan Agama Islam Siswa Kelas VIII SMPN 2 Temon Kulon Progo Tabun Pelajaran 2008/2009, Yogyakarta : Skripsi Prodi PAI Fakultas Tarbiyah UIN Sunan Kalijaga Yogyakarta

Sugiyono. 2010. Metode Penelitian Pendidikan Pendekatan Kuantitatif, Kualitatif, dan R $\sim D$, Bandung: Alfabeta

Tri Hastuti. 2005. Peran Sekolah dalam Membentuk Perilaku Keagamaan Siswa Kelas II SMPN 2 Temon, Yogyakarta : Skripsi Prodi PAI Fakultas Tarbiyah UIN Sunan Kalijaga Yogyakarta

Wasti Soemanto. 1998. Psikologi Pendidikan : Landasan Kerja Pemimpin Pendidikan. Jakarta : Rineka Cipta

Wina Sanjaya. 2008. Perencanaan dan Desain Sistem Pembelajaran. Jakarta : Prenada Media Group

Zuhairini dan Abdul Ghafir.2004. Metodologi Pendidikan Agama Islam. Malang: UM Press 